\title{
Bioaccumulation of Heavy Metals in Water, Sediments, and Tissues and Their Histopathological Effects on Anodonta cygnea (Linea, 1876) in Kabul River, Khyber Pakhtunkhwa, Pakistan
}

\author{
Muhammad Iftikhar Khan, ${ }^{1}$ Muhammad Khisroon $\left(D,{ }^{1}\right.$ Ajmal Khan ${ }^{(D)}{ }^{1}$ Naila Gulfam, \\ Muhammad Siraj, ${ }_{1}^{1}$ Farrah Zaidi, ${ }^{1}$ Ahmadullah, ${ }^{1}$ Abidullah, ${ }^{1}$ Syeda Hira Fatima, ${ }^{2}$ \\ Shumaila Noreen, ${ }^{1}$ Hamidullah, ${ }^{1}$ Zafar Ali Shah, ${ }^{3}$ and Fazli Qadir ${ }^{4}$ \\ ${ }^{1}$ Department of Zoology, University of Peshawar, Khyber Pakhtunkhwa, Pakistan \\ ${ }^{2}$ Department of Space Science, Institute of Space Technology, Islamabad, Pakistan \\ ${ }^{3}$ Department of Chemistry, University of Swabi, Khyber Pakhtunkhwa, Pakistan \\ ${ }^{4}$ Preston University, Islamabad, Pakistan
}

Correspondence should be addressed to Muhammad Khisroon; m_khisroon@uop.edu.pk and Ajmal Khan; ajmalkhan@uop.edu.pk Received 17 September 2017; Revised 24 December 2017; Accepted 22 January 2018; Published 6 March 2018

Academic Editor: Sandra Caeiro

Copyright (C) 2018 Muhammad Iftikhar Khan et al. This is an open access article distributed under the Creative Commons Attribution License, which permits unrestricted use, distribution, and reproduction in any medium, provided the original work is properly cited.

\begin{abstract}
The present investigation aimed to assess the concentrations of selected heavy metals in water and sediments and their bioaccumulation in tissues of freshwater mussels and their histopathological effects on the digestive gland, gills, and gonads of Anodonta cygnea. Water, sediments, and freshwater mussel samples were collected at four sites, that is, reference and polluted sites, along the Kabul River, Khyber Pakhtunkhwa. The polluted sites were receiving effluents from the industrial, agricultural, municipal, and domestic sources. The order of metals in the water was $\mathrm{Zn}>\mathrm{Pb}>\mathrm{Ni}>\mathrm{Cu}>\mathrm{Mn}>\mathrm{Fe}>\mathrm{Cr}>\mathrm{Cd}$, in sediments the order was $\mathrm{Fe}>\mathrm{Zn}>\mathrm{Cr}>\mathrm{Ni}>\mathrm{Mn}>\mathrm{Pb}>\mathrm{Cu}>\mathrm{Cd}$, and in the soft tissues the order was $\mathrm{Fe}>\mathrm{Zn}>\mathrm{Mn}>\mathrm{Pb}>\mathrm{Cu}>\mathrm{Cr}>\mathrm{Ni}>\mathrm{Cd}$. Histopathological alterations observed in polluted sites of Kabul River were inflammation, hydropic vacuolation, and lipofuscin pigments (in digestive gland), gill lamellar fusion, dilated hemolymphatic sinus, clumping, and generation of cilia and hemocytic infiltration (in gills), and atresia, necrosis, granulocytoma, hemocytic infiltration, and lipofuscin pigments (in gonads). The histopathological alterations in the organs of Anodonta cygnea can be considered as reliable biomarkers in biomonitoring of heavy metal pollution in aquatic ecosystems.
\end{abstract}

\section{Introduction}

Advancement in human lifestyle due to science and technology causes contamination of environment. Heavy metals are one of such pollutants that may come from both natural and human activity and could be a serious problem/threat because of their toxicity, long persistence, and bioaccumulation and biomagnification of metals in the food chain $[1,2]$. In order to assess the extent of heavy metal toxicity, it is essential to understand water quality parameters [3]. The heavy metals can react with various contents of aquatic environment and can associate with various geochemical phases in the sediments [4]. Geochemical speciation and distribution of metals in the defined chemical fraction have also been used in predicting the potential contamination, bioavailability, and mobility [5-7].

Among aquatic biota, freshwater mussels are desirable organisms for biomonitoring purposes [8-10], since these organisms are in direct contact with polluted parts of water and sediments of their habitats can accumulate high levels of heavy metals in soft parts of their bodies [11]. Freshwater mussels are sensitive indicators of chemical pollution due to 

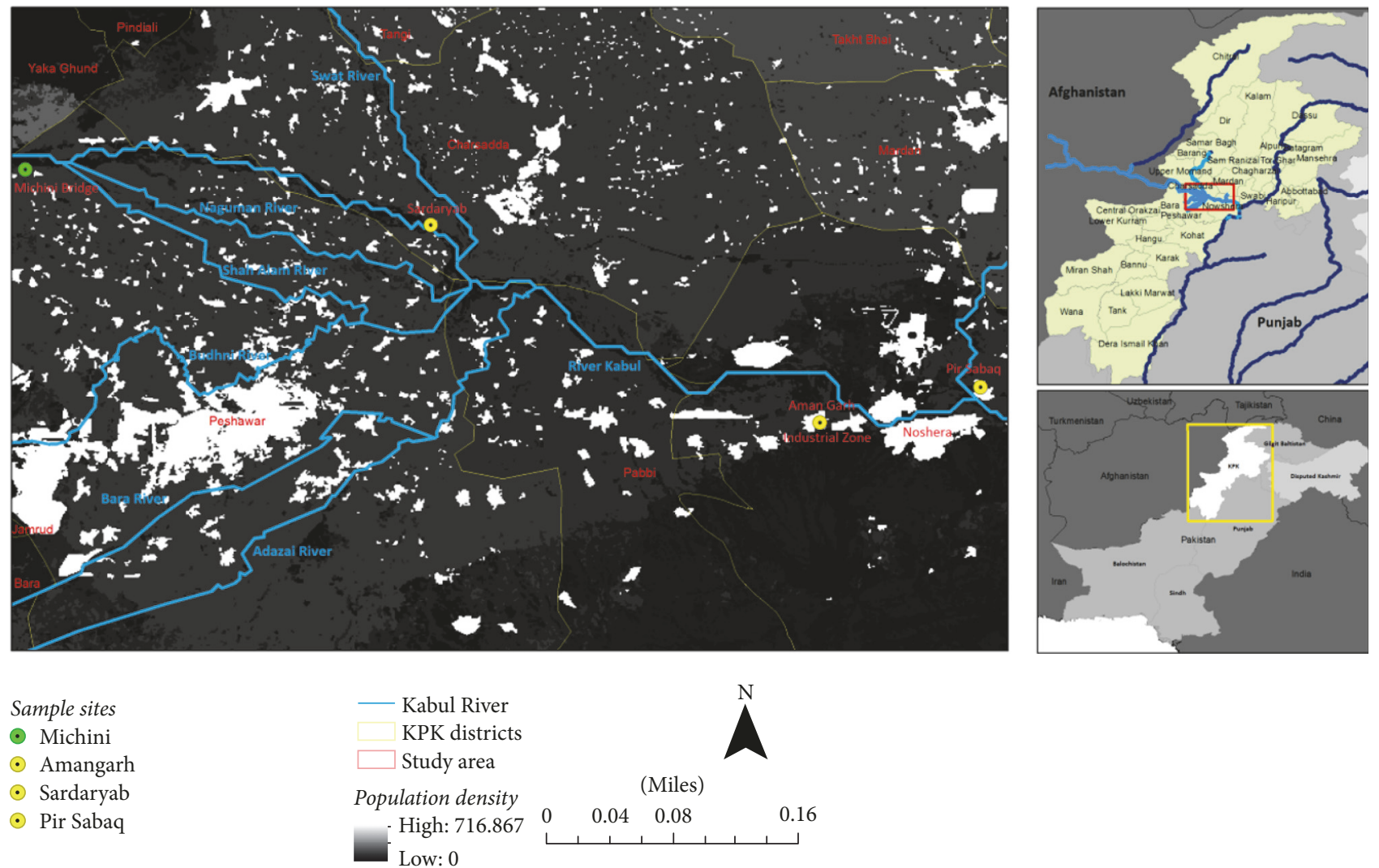

Figure 1: Kabul River and its tributaries. The control site is upstream (green circle), while the experimental sites are downstream (yellow circles). The white patches in the map show high population density regions contributing to high sewage inputs to the river.

their filtration activity $[8,12,13]$. In freshwater mussel, mantle and gills have respiratory and feeding functions $[14,15]$ and significant potential for accumulation of heavy metals and other pollutants [16-18].

The selection of histopathology as proxy of disease and contamination was based on previous researches that are indications for strong relation between pollution and the histopathology of gills, digestive glands, and gonads [19-22]. Furthermore, histopathological biomarkers have been used to monitor parasites that negatively affect bivalve, fisheries, and aquaculture industry in many countries such as Egypt, Korea, Argentina, Japan, and Spain [23-29].

This study investigated heavy metals ( $\mathrm{Cd}, \mathrm{Cr}, \mathrm{Cu}, \mathrm{Fe} \mathrm{Mn}$, $\mathrm{Ni}, \mathrm{Pb}$, and $\mathrm{Zn}$ ) in water, sediments, and soft tissues and the effect of these metals on the digestive gland, gills, and gonads of freshwater mussels from the Kabul River, Khyber Pakhtunkhwa, Pakistan.

\section{Materials and Methods}

2.1. Study Sites. Four sites along the stretch of the Kabul River in Khyber Pakhtunkhwa, Pakistan, were selected (Figure 1). The upstream site below Warsak Dam, the Michini Bridge, was designated as the reference/control site (site 1, 34.16851, $71.43245)$. In the vicinity of this site, human population density is low. Three other downstream sites at Sardaryab (site 2, 34.13338, 71.68944), Amangarh (site 3, 34.00791,
71.93622), and Pir Sabaq (site 4, 34.03035, 72.03796) were designated as polluted/experimental sites. Site 2 is receiving sewage and agricultural inputs from rural areas along the river. Site 3 is receiving sewage inputs from heavily urbanized areas alongside the tributaries such as provincial capital, Peshawar. The same site is also picking up industrial effluents from nearby Amangarh industrial estate. The fourth site is receiving effluents from all these sources and additionally from Nowshera and Mardan cities.

2.2. Collection of Water. Representative water samples $(n=$ 40) of about 1 liter were collected from the sampling sites in polypropylene $500 \mathrm{ml}$ cleaned bottles. At the sampling time, these bottles were also washed with the respective river water. The samples were collected below the surface about 2-3 feet away from the river banks in such a way that no bubbles were allowed. These water samples were filtered and preserved in $5 \mathrm{ml}$ of $55 \% \mathrm{HNO}_{3}$ per liter of water to prevent metal adsorption on the inner surface of the container and stored at $4^{\circ} \mathrm{C}$ before their analyses.

2.3. Collection of Sediments. $50 \mathrm{~g}$ sediment samples $(n=$ 10) were collected from a depth of $15 \mathrm{~cm}$ from the surface from each site, using a sediment collector with an acidwashed plastic scoop and transported to the laboratory in polyethylene bags. They were dried and passed through a $2 \mathrm{~mm}$ sieve. 
TABLE 1: Length, width, mussel weight, and mussel flesh (mean \pm standard deviation) of Anodonta cygnea.

\begin{tabular}{lccccc}
\hline Site & Number & Length $(\mathrm{mm})$ & Width $(\mathrm{mm})$ & Mussel weight $(\mathrm{g})$ & Mussel flesh $(\mathrm{g})$ \\
\hline Michini Bridge & 20 & $113.7 \pm 7.9$ & $87.4 \pm 6.3$ & $239.6 \pm 14.9$ & $56.3 \pm 5.6$ \\
Sardaryab & 20 & $109.4 \pm 4.5$ & $92.3 \pm 5.9$ & $213.8 \pm 8.4$ & $63.2 \pm 7.2$ \\
Amangarh & 20 & $105.2 \pm 9.1$ & $72.1 \pm 5.3$ & $189.3 \pm 11.8$ & $39.2 \pm 5.3$ \\
Pir Sabaq & 20 & $87.9 \pm 9.5$ & $74.2 \pm 9.3$ & $145.9 \pm 9.7$ & $34.9 \pm 5.9$ \\
\hline
\end{tabular}

TABLE 2: The standards used to analyze the variable using atomic absorption spectrophotometer (Spectra-AA-700).

\begin{tabular}{lclc}
\hline Metals & Wavelength $(\mathrm{nm})$ & Flame & Working range $(\mu \mathrm{g} / \mathrm{mL})$ \\
\hline $\mathrm{Cd}$ & 228.8 & AA (R) & $0.5-2$ \\
$\mathrm{Cr}$ & 357.9 & AA (R) & $2-8$ \\
$\mathrm{Cu}$ & 324.8 & AA (L) & $2-8$ \\
$\mathrm{Fe}$ & 279.5 & AA (L) & $1-4$ \\
$\mathrm{Ni}$ & 324.7 & AA (L) & $3-12$ \\
$\mathrm{~Pb}$ & 283.3 & AA (L) & $5-20$ \\
$\mathrm{Mn}$ & 248.3 & AA (L) & $1-4$ \\
$\mathrm{Zn}$ & 213.9 & AA (L) & $0.4-1$ \\
\hline
\end{tabular}

AA, air acetylene; $R$, fuel-rich; $L$, fuel-lean.

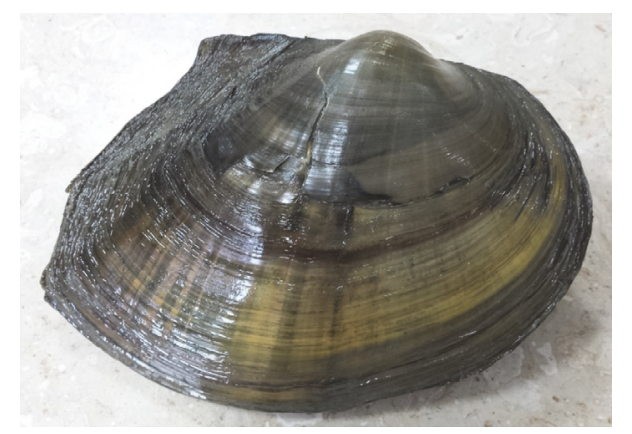

Figure 2: Freshwater mussel (Anodonta cygnea).

2.4. Collection of Freshwater Mussel Samples. Freshwater mussels $(n=80)$ were collected from their natural populations at the four respective sites. The species sampled for the present study was Anodonta cygnea (Figure 2). The mussels were collected by hand and placed into clean containers holding water. They were transported to the laboratory, where 40 mussels were kept in $15 \mathrm{~L}$ of water for 6 to 7 days. The length, width, and total weight of the mussels were noted (Table 1). Sterilized stainless steel scalpel was used to remove the soft tissue in a laminar flow cabinet lined with a Teflon base. The flesh samples were oven-dried at $60^{\circ} \mathrm{C}$ and reweighed to determine the dry weight, which is typically only $5-10 \%$ of the mussel wet weight, and were depurated overnight in clean and filtered water.

2.5. Metal Estimation in Water Samples. $100 \mathrm{ml}$ of acidified water samples was evaporated in a volumetric flask on a hot plate and reduced to about $20 \mathrm{ml}$ within a fume cupboard and then a mixture of $5 \mathrm{ml}$ of $\mathrm{HNO}_{3}(55 \%)$ and $10 \mathrm{ml}$ of perchloric acid $(70 \%)$ was added. The mixture was evaporated on a hot plate until the brown fumes converted into dense white fumes of perchloric acid. The samples were cooled and diluted to $100 \mathrm{ml}$ with double distilled water. The solutions were then analyzed through atomic absorption spectrophotometer (Spectra-AA-700) by using an air acetylene flame for the determination of these metals (Table 2).

2.6. Metal Estimation in Sediment Samples. The same procedure was carried out on $5 \mathrm{~g}$ of dried sediment samples.

2.7. Metal Analysis in Freshwater Mussel Tissues. Metal detection in all the soft tissues was determined by using the method described by Siraj et al. [30]. Briefly, tissues were rinsed with double deionized water and kept on blotting paper. $50 \mathrm{~g}$ of each tissue was placed in separate $100 \mathrm{ml}$ volumetric flask. Tissues were digested in $5 \mathrm{ml}$ mixed solution of perchloric and nitric acid. The next day, a fresh mixture of the two acids was added to each tissue. The tissues containing flasks were placed on hot plate and allowed to digest at 200 to $250^{\circ} \mathrm{C}$ until a transparent and clear solution was obtained. $100 \mathrm{ml}$ double distilled water was added to digested tissues. Heavy metals were analyzed through atomic absorption spectrophotometer (Spectra-AA-700) by using an air acetylene flame for the determination of metals. The dissected samples were fixed in calcium-formaldehyde solution (40\% formaldehyde and $10 \%$ calcium) and dehydrated in alcohols using ethanol. The mussels were cut at plane so as to include gills, gonads, and digestive gland. Tissues were dehydrated by placing them in $70 \%, 95 \%$, and finally $100 \%$ ethanol. Ethanol from tissues was removed in methyl benzoate solution and then rinsed in benzene and embedded in paraffin. Histological sections $(7 \mu \mathrm{m}$ thick) were cut on a microtome HM335s (Microm $\mathrm{GmbH}$, Bergman, Germany) mounted on slides, dried at $37^{\circ} \mathrm{C}$ for $24 \mathrm{~h}$, and stored at room temperature until staining. Up to twenty mussels tissue thin sections per site were stained with hematoxylin and eosin and examined for histopathological abnormalities. Sections were studied under 
TABLE 3: Mean concentration of metals $(\mu \mathrm{g} / \mathrm{l})$ in water from Michini Bridge below Warsak Dam (reference site/site 1), Sardaryab, Amangarh, and Pir Sabaq (polluted sites 2, 3, and 4) of River Kabul receiving industrial effluents and city sewages and permissible limits of these metals according to NEQS.

\begin{tabular}{|c|c|c|c|c|c|}
\hline Metals $(\mu \mathrm{g} / \mathrm{l})$ & Site 1 & Site 2 & Site 3 & Site 4 & NEQS $(\mu \mathrm{g} / \mathrm{L})$ \\
\hline $\mathrm{Cd}$ & $7.0 \pm 4.0$ & $82.3 \pm 1.1^{* *}$ & $27.0 \pm 1.7^{*}$ & $90.6 \pm 3.7^{* *}$ & 100 \\
\hline $\mathrm{Cr}$ & $36.3 \pm 4.9$ & $51.0 \pm 2.0^{*}$ & $56.0 \pm 4.3^{*}$ & $64.0 \pm 1.0^{* *}$ & 1000 \\
\hline $\mathrm{Cu}$ & $24.3 \pm 9.0$ & $28.0 \pm 1.1^{*}$ & $27.6 \pm 1.1^{*}$ & $32.0 \pm 3.0^{*}$ & 1000 \\
\hline $\mathrm{Fe}$ & $25.0 \pm 5.0$ & $53.0 \pm 2.0^{* *}$ & $56.0 \pm 1.5^{* *}$ & $63.6 \pm 6.1^{* *}$ & 8000 \\
\hline $\mathrm{Ni}$ & $68.0 \pm 2.6$ & $71.0 \pm 1.0$ & $76.0 \pm 1.0$ & $78.3 \pm 0.5^{*}$ & 1000 \\
\hline $\mathrm{Pb}$ & $32.0 \pm 6.0$ & $170.3 \pm 5.0^{* *}$ & $182.0 \pm 5.29^{* *}$ & $186.3 \pm 6.1^{* *}$ & 500 \\
\hline $\mathrm{Mn}$ & $29.0 \pm 5.0$ & $56.0 \pm 0.5^{* *}$ & $61.0 \pm 2.0^{* *}$ & $64.0 \pm 1.0^{* *}$ & 1500 \\
\hline $\mathrm{Zn}$ & $104.3 \pm 4.0$ & $237.3 \pm 5.1^{* *}$ & $243.3 \pm 3.7^{* *}$ & $247.3 \pm 2.0^{* *}$ & 500 \\
\hline
\end{tabular}

Data is shown as Mean \pm SD. NEQS, National Environmental Quality Standards. Difference is significant relative to site 1 at ${ }^{*} P<0.01$ and ${ }^{* *} P<0.001$.

light microscope for parasitic infestation assessment and pathological alterations in the target tissues.

2.8. Statistical Analysis. One-way analysis of variance (ANOVA) test was used to compare the different sets of data collected from the polluted sites to that of reference site; $P<0.05$ was considered to show statistical significance, using SPSS v.20.0 software for Windows.

\section{Results and Discussions}

3.1. Concentration of Heavy Metals in Water. The results given in Table 2 indicate heavy metal concentrations in water samples collected from sites 1 (reference site), 2, 3, and 4 . The concentrations of heavy metals in water samples from both polluted and reference sites were within permissible limits as laid down by NEQS 1997 [31]. However, the respective concentrations of metals showed gradual hike from site 1 to site 4 with metal concentrations for sites 2,3 , and 4 being significantly higher than site 1 (Table 3 ). The value of zinc was relatively high at the reference site 1 (Table 3), which is understandable as Kabul River originates from Paghman Mountains, so high levels of $\mathrm{Zn}$ in headwaters can be associated with release of $\mathrm{Zn}$ from various minerals and rocks [32]. With respect to site 1 , the levels of zinc were significantly high at the other three sites (Table 2) which can be attributed to addition of domestic and industrial effluents. In Pakistan, these two sources contribute significantly to zinc pollution in freshwater systems [33-35]. Khan et al. [33] found $\mathrm{Zn}$ as the second highest metal in Shah Alam River $(\mathrm{Ni}, \mathrm{Zn}, \mathrm{Cu}$, and $\mathrm{Pb})$ at polluted sites near Peshawar city. A study from Punjab province showed $\mathrm{Zn}$ and $\mathrm{Cu}$ as the highest metals in River Ravi water at Balloki Headworks [34]. A similar study on heavy metals in the water of River Sutlej at Sulemanki Headworks showed $\mathrm{Zn}$ as the second most accumulated metal [35]. Indeed across the globe industrial and sewage discharges are considered the most important sources of surface water pollution [36].

3.2. Concentration of Heavy Metals in Sediments. The metals in the sediments were in the order of $\mathrm{Fe}>\mathrm{Zn}>\mathrm{Cr}>\mathrm{Ni}>$ $\mathrm{Mn}>\mathrm{Pb}>\mathrm{Cu}>\mathrm{Cd}$. The sediments samples from polluted sites 2, 3, and 4 showed the highest levels of metals, while the reference site demonstrated lowest values (Table 4). In consensus with the present study, Tabinda et al. [34] showed Fe and $\mathrm{Zn}$ as the highest metals accumulated in the sediments of River Ravi. Large amount of heavy metals that are bound in sediments due to high surface area and content of humic substances can be released into the water by movements of aquatic organisms [35, 37].

3.3. Concentration of Heavy Metals in Soft Tissues of Freshwater Mussels. Bioaccumulation showed peak values in soft tissues of freshwater mussels collected from polluted sites 2-4. The difference was significant when compared to reference site 1 with least pollution (Table 5). The order of these metals in soft tissues of freshwater mussels was $\mathrm{Fe}>\mathrm{Zn}>\mathrm{Mn}>\mathrm{Pb}$ $>\mathrm{Cu}>\mathrm{Cr}>\mathrm{Ni}>\mathrm{Cd}$. The higher values are due to low detoxification mechanisms, low metabolic rates, direct exposure of the tissues to metals, and lower rate of elimination of metals. In our study, the degree of metal accumulation in soft tissues followed the same order and spatial variations as found in the associated sediments. Similar results have been presented by a number of studies that demonstrate the sensitivity of mussels to slight changes in heavy metal concentrations in their aquatic habitat [38-40]. Thus, mussel soft tissue can be used to examine environmental conditions over shorter time scales. Heavy metal contents in mussel hemolymph, foot, and mantle tissue can be used as sublethal biomarkers to monitor water quality, stress, or immune responses [18, 19, 4143]. For several decades, Unionidae family has been used for monitoring pollution status of lakes and rivers $[19,39$, $40,44]$. There are a significant number of reports on heavy metals and other elements in adult mussels [45-47] since the Mussel Watch concept was proposed by Goldberg [48]. The selection criteria for being a good pollution indicator do not solely depend on its accumulative index for the particular parameter [45-47]. It also considers other factors such as parasite burden and histological alterations.

3.4. Parasitic Infestation. The specimens of freshwater mussels were found to be infected with Rickettsia-like organisms (RLOs). Figure 3 shows the density of parasites in the samples from all collection sites. The organ wise density was digestive 
TABle 4: Mean concentration of metals $(\mathrm{mg} / \mathrm{Kg}$ ) in sediments from Michini Bridge below Warsak Dam (reference site/site 1), Sardaryab, Amangarh, and Pir Sabaq (polluted sites 2, 3, and 4) of River Kabul receiving industrial effluents and city sewages.

\begin{tabular}{lcccc}
\hline Metals $(\mathrm{mg} / \mathrm{kg})$ & Site 1 & Site 2 & Site 3 & Site 4 \\
\hline $\mathrm{Cd}$ & $4.4 \pm 2.6$ & $5.0 \pm 1.3^{*}$ & $4.9 \pm 1.7^{*}$ & $7.1 \pm 1.8^{*}$ \\
$\mathrm{Cr}$ & $75.5 \pm 24.8$ & $85.4 \pm 15.4$ & $92.0 \pm 10.2$ & $92.5 \pm 12.8$ \\
$\mathrm{Cu}$ & $10.9 \pm 2.9$ & $14.2 \pm 6.9$ & $14.1 \pm 6.5$ & $15.3 \pm 8.8$ \\
$\mathrm{Fe}$ & $270.0 \pm 97.9$ & $344.6 \pm 115.6^{*}$ & $382.6 \pm 43.3^{* *}$ & $591.3 \pm 153.5^{*}$ \\
$\mathrm{Ni}$ & $69.1 \pm 18.8$ & $85.1 \pm 3.6^{* *}$ & $68.5 \pm 13.3$ & $82.6 \pm 17.6^{*}$ \\
$\mathrm{~Pb}$ & $32.8 \pm 18.2$ & $40.3 \pm 15.0^{*}$ & $44.0 \pm 9.7^{*}$ & $54.6 \pm 4.3^{* *}$ \\
$\mathrm{Mn}$ & $73.2 \pm 24.8$ & $78.3 \pm 20.4$ & $80.26 \pm 8.1$ & $83.7 \pm 6.9^{* *}$ \\
$\mathrm{Zn}$ & $85.9 \pm 10.5$ & $86.4 \pm 7.0^{*}$ & $81.3 \pm 16.8$ & $88.3 \pm 7.9^{* *}$ \\
\hline
\end{tabular}

Data is shown as Mean \pm SD. Difference is significant relative to site 1 at ${ }^{*} P<0.05$ and ${ }^{* *} P<0.001$.

TABLE 5: Mean concentration of metals ( $\mu \mathrm{g} / \mathrm{g}$ wet weight) in soft tissues of freshwater mussels collected from Michini Bridge below Warsak Dam (reference site/site 1), Sardaryab, Amangarh, and Pir Sabaq (polluted sites 2, 3, and 4) of River Kabul receiving industrial effluents and city sewages.

\begin{tabular}{lcccc}
\hline Metals $(\mathrm{mg} / \mathrm{kg})$ & Site 1 & Site 2 & Site 3 & Site 4 \\
\hline $\mathrm{Cd}$ & $0.9 \pm 0.8$ & $1.2 \pm 0.7$ & $1.2 \pm 0.9$ & $1.0 \pm 0.6$ \\
$\mathrm{Cr}$ & $1.1 \pm 0.9$ & $1.5 \pm 0.7$ & $1.7 \pm 0.9$ & $1.8 \pm 0.9^{*}$ \\
$\mathrm{Cu}$ & $2.7 \pm 1.3$ & $3.6 \pm 0.6$ & $3.2 \pm 0.9$ & $3.3 \pm 1.0$ \\
$\mathrm{Fe}$ & $76.3 \pm 31.6$ & $101.0 \pm 30.3$ & $162.3 \pm 90.2^{* * *}$ & $136.2 \pm 62.3^{* *}$ \\
$\mathrm{Ni}$ & $1.5 \pm 0.9$ & $2.3 \pm 1.0$ & $1.6 \pm 1.1$ & $2.7 \pm 4.7$ \\
$\mathrm{~Pb}$ & $10.1 \pm 10.7$ & $26.5 \pm 11.2^{* * *}$ & $26.1 \pm 7.3^{* * *}$ & $31.9 \pm 11.9^{* * *}$ \\
$\mathrm{Mn}$ & $35.1 \pm 12.7$ & $38.2 \pm 13.5$ & $39.9 \pm 13.7$ & $45.3 \pm 19.5^{*}$ \\
$\mathrm{Zn}$ & $41.7 \pm 16.6$ & $46.1 \pm 13.7$ & $47.4 \pm 13.2$ & $50.4 \pm 13.7^{*}$ \\
\hline
\end{tabular}

Difference is significant relative to site 1 at ${ }^{*} P<0.05,{ }^{* *} P<0.01$, and ${ }^{* * *} P<0.001$.

gland $>$ gills $>$ gonads. The RLOs are intracellular bacterial parasites, known to be common in invertebrates, mussels in particular. The population of freshwater mussels was severely infected with RLOs at downstream sites of Amangarh and Pir Sabaq. Amangarh, in addition to pollution by industrial and domestic effluents, is grossly contaminated [31]. Hence, severe RLOs infection rate is found in the mussels samples collected from Amangarh as compared to other sites.

\subsection{Histological Study}

3.5.1. Digestive Glands. Histopathological alterations found in digestive gland were atrophy, hydropic vacuolation, necrosis, and lipofuscin. All four types of lesions were present in specimens from all the collection sites. Their percentage wise distribution is shown in Figure 4. Samples from Amangarh possessed 68\% atrophy, while those of Pir Sabaq showed 72\% lipofuscin pigments. In other studies, high vacuolation in digestive tubules has been found in clam and mussels $[49,50]$.

3.5.2. Gills. Histopathological alterations found in gills were lamellar fusion, dilated hemolymphatic sinus, degeneration of cilia, and hemocytic infiltration. Amangarh showed the highest degeneration of cilia, while Pir Sabaq manifests higher value of hemocytic infiltration. Samples collected from Amangarh had higher percentage $(85 \%)$ of degeneration of cilia in gills (Figure 5).
3.5.3. Gonads. Histopathological alterations found were atresia, necrosis, granulocytoma, hemocytic infiltration, and lipofuscin pigments in gonads. Atresia (75\%) was in highest prevalence in mussels from Sardaryab and Amangarh, while in the mussels samples from Michini Bridge, all other lesions were present except atresia (Figure 6).

Kabul River flowing through Pakistan has a number of biochemical characteristics. The dissolved oxygen levels within the river are generally good and above the usually recommended values, $5 \mathrm{gm} / \mathrm{l}$, necessary for fisheries and aquatic life. BOD values within the river are generally acceptable. However, the downstream region is stressful for aquatic life and subject to organic pollution [51]. Now well established, most of the histopathological observations in an organism are related to environmental stresses [52]. Previous studies show increased mortality in freshwater mussels when exposed to metals [53]. Obviously other factors also play important role and one should also consider factor interaction.

The present study outlines major problems associated with heavy metal pollution in Kabul River. However, certain limitations are also linked to the study. Firstly, the river index should be calculated; secondly, the polycyclic aromatic hydrocarbons (PAHs) in the water, sediments, and mussel tissues should be estimated as they might contribute to the pollution and their consequences in the river fauna.

In Pakistan, few studies have been carried out to observe the effects of heavy metal pollution in aquatic or land 


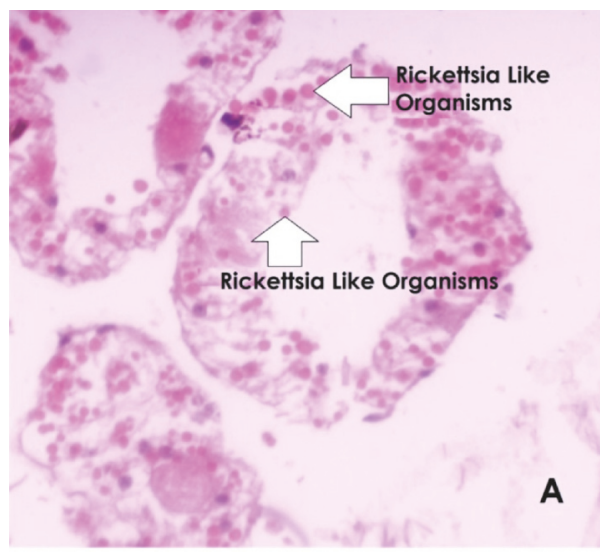

(a)

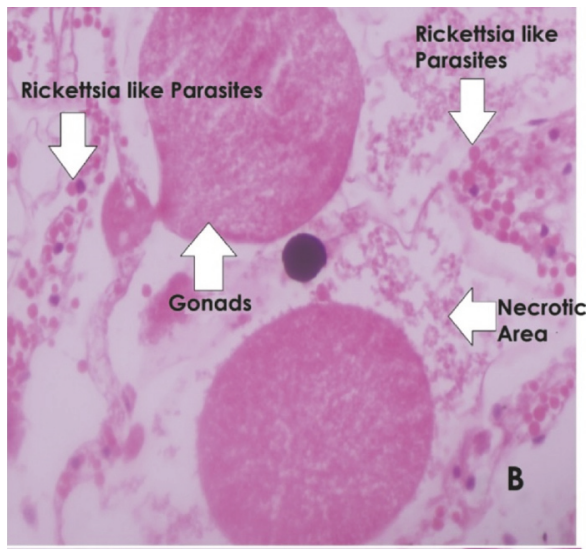

(b)

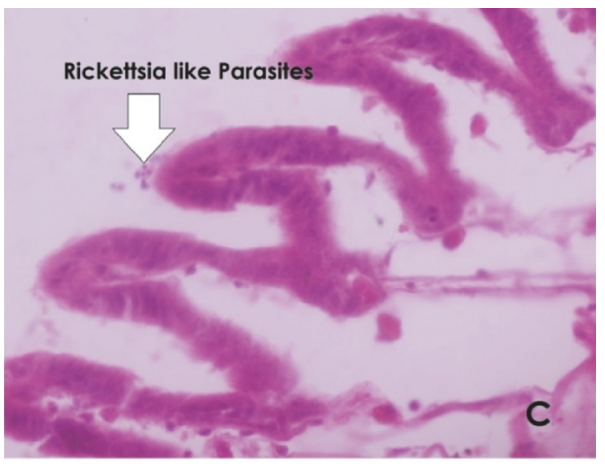

(c)

Figure 3: (a) Section of digestive gland showing Rickettsia-like organism $(\times 400)$. (b) Section of gonads showing Rickettsia-like organism $(\times 400)$. (c) Section of gills showing Rickettsia-like organism $(\times 400)$.

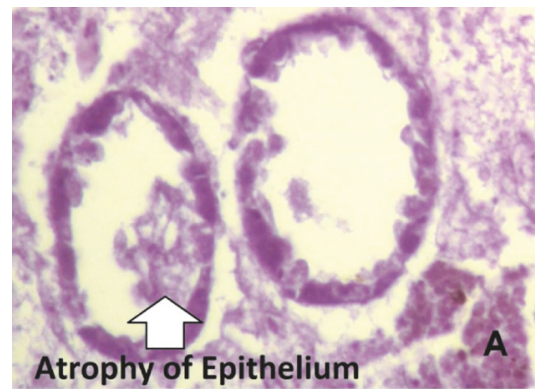

(a)

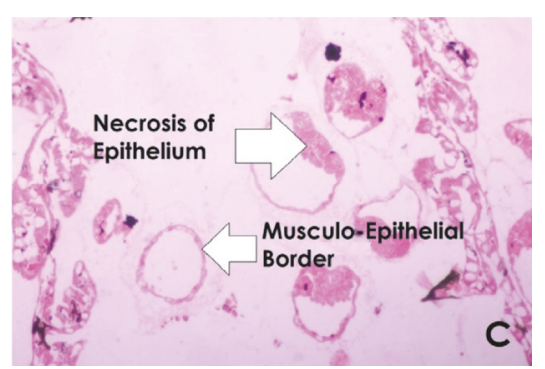

(c)

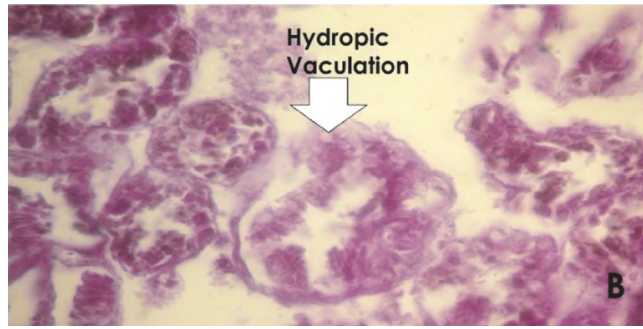

(b)

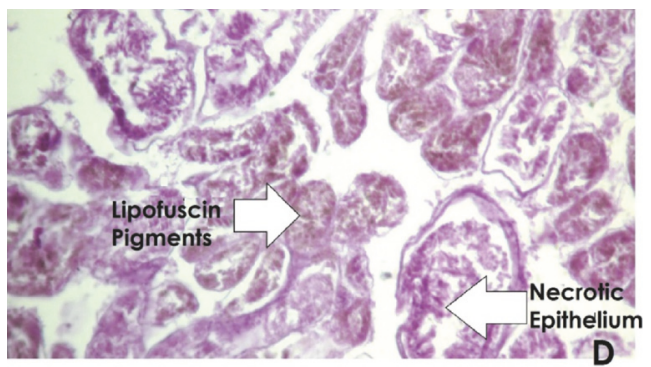

(d)

FIGURE 4: Section of digestive gland showing (a) atrophy of epithelium $(\times 400)$, (b) hydropic vacuolation $(\times 400)$, (c) necrosis of epithelium $(\times 400)$, and (d) lipofuscin pigments $(\times 400)$. 


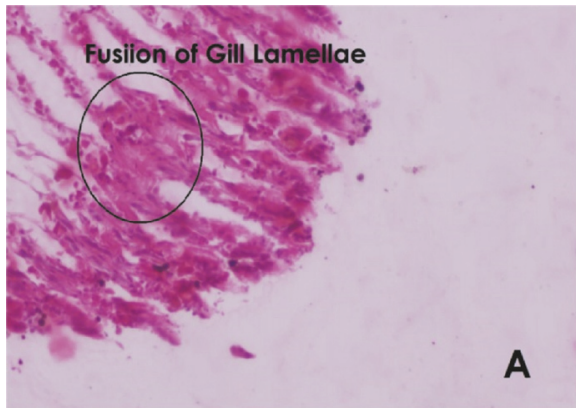

(a)

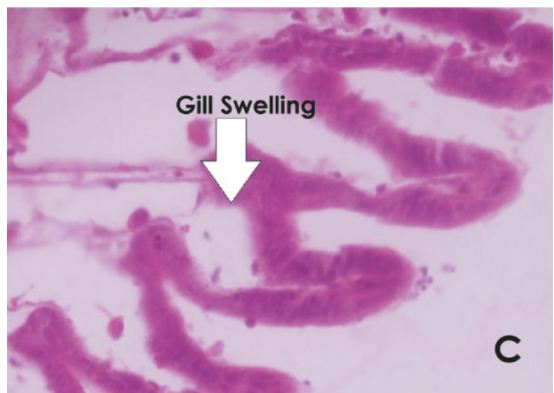

(c)

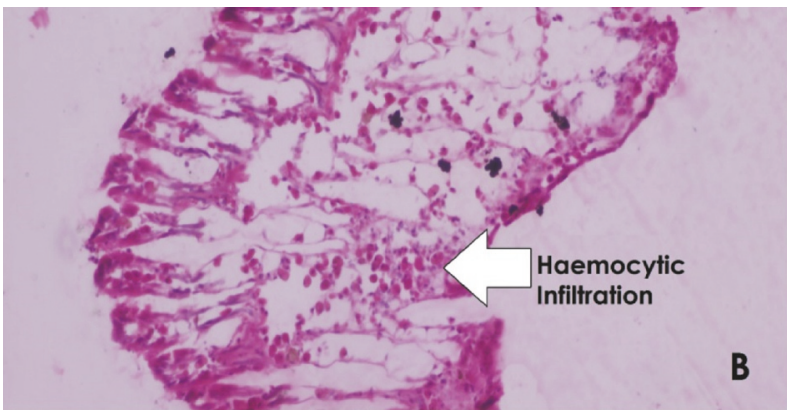

(b)

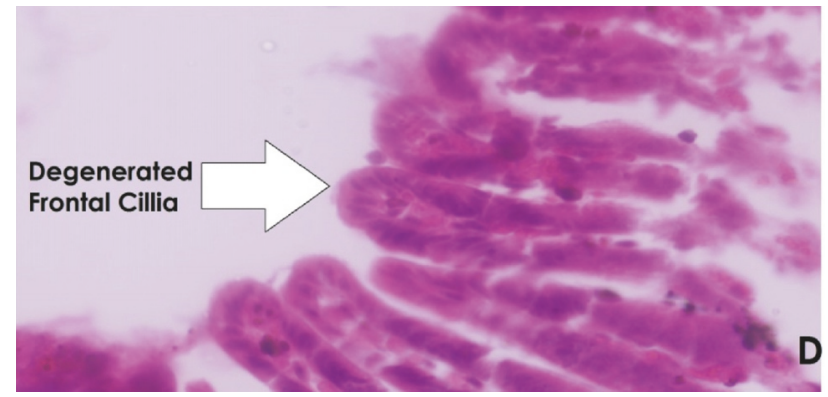

(d)

FIGURE 5: Section of gills showing (a) fusion of gills lamellae $(\times 400)$, (b) hemocytic infiltration $(\times 400)$, (c) gills swelling $(\times 400)$, and $(d)$ degenerated frontal gills $(\times 400)$.

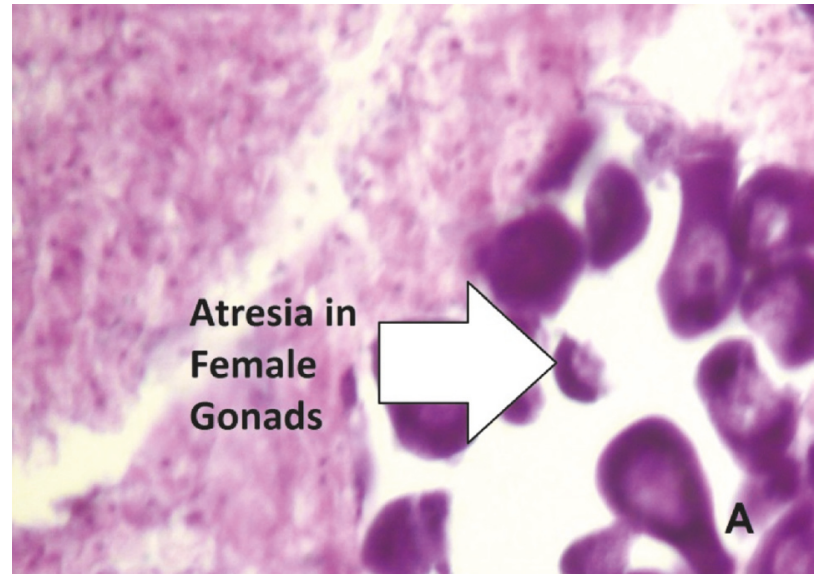

(a)

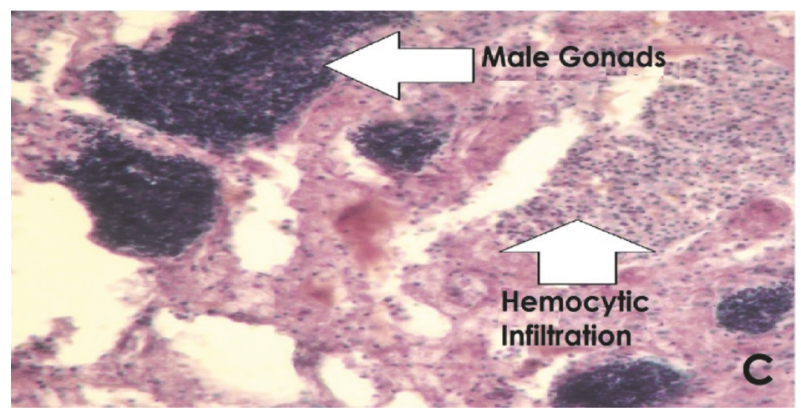

(c)

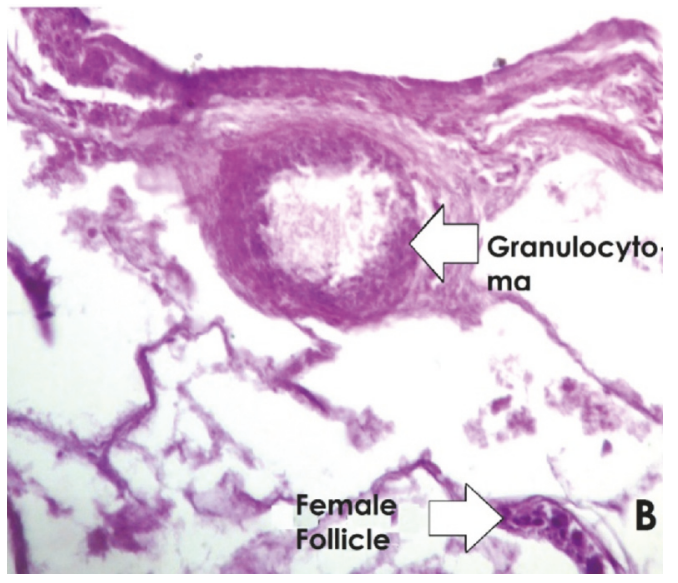

(b)

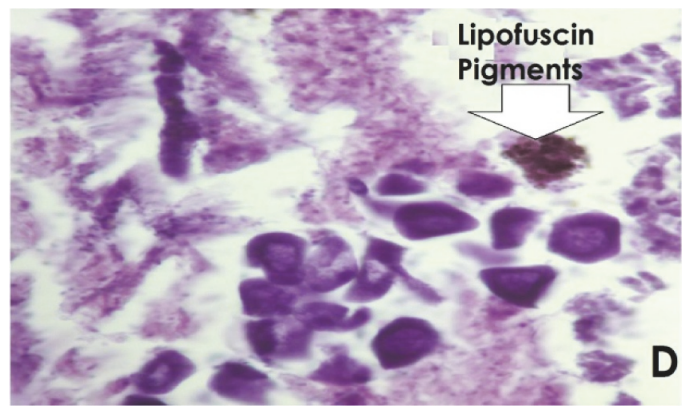

(d)

Figure 6: Section of gonads showing (a) atresia in female gonads $(\times 400),(b)$ granulocytoma $(\times 400)$, (c) hemocytic infiltration $(\times 400)$, and (d) lipofuscin pigments $(\times 400)$. 
ecosystems [54]. The consequences of heavy metal bioaccumulation and biomagnification on food chains should be further explored in the riverine habitats of the region. In this regard, present study lays the foundation for future research on local riverine ecology. Nevertheless, to enhance our knowledge of heavy metal pollution and its role in bioaccumulations and histopathological changes, further studies are quintessential.

\section{Conclusion}

In conclusion, the results indicate high concentrations of $\mathrm{Cd}, \mathrm{Cr}, \mathrm{Cu}, \mathrm{Fe}, \mathrm{Mn} \mathrm{Ni}, \mathrm{Pb}$, and $\mathrm{Zn}$ in Kabul River. The study highlights the capability of heavy metals for bioaccumulation in the tissues of freshwater mussels and reveals histopathological alterations in mussel tissues. The study elaborates on vulnerability of riverine ecosystems to low levels of perturbation, that is, heavy metal pollution. It shows occurrence of bioaccumulation at permissible levels of pollutants. It further emphasizes the need of pollution mitigation activities in habitats of Kabul River. The results of this study are well under the scope and our main aims sand objectives of the study. The authorities should take necessary actions to save the river from pollution hazards.

\section{Conflicts of Interest}

The authors declare that they have no conflicts of interest regarding the publication of this paper.

\section{Authors' Contributions}

Muhammad Iftikhar Khan, Muhammad Khisroon, Ajmal Khan, and Farrah Zaidi contributed equally to this work.

\section{References}

[1] R. Eisler, "Zinc hazards to fish, wildlife and invertebrates: a synoptic review," US Fish Wildlife Service Reproductive Biology, vol. 85, pp. 1-6, 1986.

[2] S. Pandey, S. Parvez, I. Sayeed, R. Haque, B. Bin-Hafeez, and S. Raisuddin, "Biomarkers of oxidative stress: a comparative study of river Yamuna fish Wallago attu (Bl. \& Schn.)," Science of the Total Environment, vol. 309, no. 1-3, pp. 105-115, 2003.

[3] F. Ambreen and M. Javed, "Assessment of acute toxicity of pesticides mixtures for Cyprinus carpio and Ctenopharyngodon idella," Pakistan Journal of Zoology, vol. 47, pp. 133-139, 2015.

[4] J. Morillo, J. Usero, and I. Gracia, "Heavy metal distribution in marine sediments from the southwest coast of Spain," Chemosphere, vol. 55, no. 3, pp. 431-442, 2004.

[5] C. Kabala and B. R. Singh, "Fractionation and mobility of copper, lead, and zinc in soil profiles in the vicinity of a copper smelter," Journal of Environmental Quality, vol. 30, no. 2, pp. 485-492, 2001.

[6] M. Pueyo, J. Sastre, E. Hernandez, M. Vidal, J. F. Lopez-Sanchez, and G. Rauret, "Heavy metals in the environment: prediction of trace element mobility in contaminated soils by sequential extraction," Journal of Environmental Quality, vol. 32, no. 6, pp. 2054-2066, 2003.
[7] S. Caeiro, M. H. Costa, T. B. Ramos et al., "Assessing heavy metal contamination in Sado Estuary sediment: an index analysis approach," Ecological Indicators, vol. 5, no. 2, pp. 151-169, 2005.

[8] M. Fournier, J. Pellerin, Y. Clermont, Y. Morin, and P. Brousseau, "Effects of in vivo exposure of Mya arenaria to organic and inorganic mercury on phagocytic activity of hemocytes," Toxicology, vol. 161, no. 3, pp. 201-211, 2001.

[9] B. Andral, J. Y. Stanisiere, D. Sauzade et al., "Monitoring chemical contamination levels in the Mediterranean based on the use of mussel caging," Marine Pollution Bulletin, vol. 49, no. 9-10, pp. 704-712, 2004.

[10] A. Viarengo, D. Lowe, C. Bolognesi, E. Fabbri, and A. Koehler, "The use of biomarkers in biomonitoring: a 2-tier approach assessing the level of pollutant-induced stress syndrome in sentinel organisms," Comparative Biochemistry and Physiology, vol. 146, no. 3, pp. 281-300, 2007.

[11] J. L. Farris and J. H. Van Hassel, Freshwater Bivalve Ecotoxicology, CRC Press, New York, NY, USA, 2007.

[12] C. L. Atkinson and C. C. Vaughn, "Biogeochemical hotspots: Temporal and spatial scaling of the impact of freshwater mussels on ecosystem function," Freshwater Biology, vol. 60, no. 3, pp. 563-574, 2015.

[13] G. W. Chowdhury, A. Zieritz, and D. C. Aldridge, "Ecosystem engineering by mussels supports biodiversity and water clarity in a heavily polluted lake in Dhaka, Bangladesh," Freshwater Science, vol. 35, no. 1, pp. 188-199, 2016.

[14] E. Gosling, Bivalve Molluscs: Biology, Ecology and Culture, Blackwell, New York, NY, USA, 2003.

[15] J. S. Bril, J. J. Durst, B. M. Hurley, C. L. Just, and T. J. Newton, "Sensor data as a measure of native freshwater mussel impact on nitrate formation and food digestion in continuous-flow mesocosms," Freshwater Science, vol. 33, no. 2, pp. 417-424, 2014.

[16] S. Chakraborty, M. Ray, and S. Ray, "Toxicity of sodium arsenite in the gill of an economically important mollusc of India," Fish and Shellfish Immunology, vol. 29, no. 1, pp. 136-148, 2010.

[17] E. J. Jasinska, G. G. Goss, P. L. Gillis et al., "Assessment of biomarkers for contaminants of emerging concern on aquatic organisms downstream of a municipal wastewater discharge," Science of the Total Environment, vol. 530-531, pp. 140-153, 2015.

[18] S. Kolarevic, M. Kracun-Kolarevic, J. Kostic et al., "Assessment of the genotoxic potential along the Danube River by application of the comet assay on haemocytes of freshwater mussels: the joint Danube Survey 3," Science of the Total Environment, vol. 540, pp. 377-385, 2016.

[19] G. P. Domouhtsidou and V. K. Dimitriadis, "Ultrastructural localization of heavy metals $(\mathrm{Hg}, \mathrm{Ag}, \mathrm{Pb}$, and $\mathrm{Cu}$ ) in gills and digestive gland of mussels, Mytilus galloprovincialis (L.)," Archives of Environmental Contamination and Toxicology, vol. 38, no. 4, pp. 472-478, 2000.

[20] I. M. Sokolova, "Cadmium effects on mitochondrial function are enhanced by elevated temperatures in a marine poikilotherm, Crassostrea virginica Gmelin (Bivalvia: Ostreidae)," Journal of Experimental Biology, vol. 207, no. 15, pp. 2639-2648, 2004.

[21] I. M. Sokolova, S. Evans, and F. M. Hughes, "Cadmium-induced apoptosis in oyster hemocytes involves disturbance of cellular energy balance but no mitochondrial permeability transition," Journal of Experimental Biology, vol. 207, no. 19, pp. 3369-3380, 2004.

[22] M. I. Khan, Z. Ayub, and G. Siddiqui, "Impact of marine pollution in green mussels, Pernaviridis from four coastal sites 
in Karachi, Pakistan, North Araabian Sea; histopathological observations," Indian Journal of Experimental Biology, vol. 53, pp. 222-227, 2015.

[23] R. A. M. Ramadan and M. M. Ahmad, "Infestation of Donaxtrunculus (Bivalvia, Donacidae) from Mediterranean Sea at Port Said coastal zone with Baccigerbacciger (Trematoda, Fellodistomidae) and the role of the parasite in castration of the host," African Journal of Biological Science, vol. 6, pp. 83-94, 2010.

[24] M. M. El-Gamal, "Detection of trematode larvae in Donaxtruculus (Mollusca: Bivalvia) from Egypt," in Proceedings of the 6th International Conference on Biological Science (Zoology), vol. 6, pp. 296-305, 2010.

[25] K.-I. Park and K.-S. Choi, "Spatial distribution of the protozoan parasite Perkinsus sp. found in the Manila clams, Ruditapes philippinarum, in Korea," Aquaculture, vol. 203, no. 1-2, pp. 922, 2001.

[26] F. Cremonte, A. Figueras, and E. M. Burreson, "A histopathological survey of some commercially exploited bivalve molluscs in northern Patagonia, Argentina," Aquaculture, vol. 249, no. 1-4, pp. 23-33, 2005.

[27] F. Brusa, N. Vázquez, and F. Cremonte, "Paravortex panopea n. sp. (Platyhelminthes: Rhabdocoela) on clams from the northern Patagonian coast, Argentina: pathogeny and specificity," Helminthologia, vol. 48, no. 2, pp. 94-100, 2011.

[28] I. H. Kim and S. I. Sato, "A review of copepods associated with bivalves in Japan, with description of two new species (Crustacea, Copepoda, Cyclopoida)," Bulletin of the Tohoku University Museum, vol. 9, pp. 1-22, 2010.

[29] Cremonte, "Diseases of bivalve molluscs of commercial interest caused by metazoans," in Diseases of bivalve molluscs of interest in Aquaculture, A. Figueras and B. Novoa, Eds., pp. 331385, Scientific and Technological Publications of the Spanish Aquaculture Observatory, Madrid, Spain, 2011.

[30] M. Siraj, M. Khisroon, and A. Khan, "Bioaccumulation of heavy metals in different organs of Wallago attu from River Kabul Khyber Pakhtunkhwa, Pakistan," Biological Trace Element Research, vol. 172, no. 1, pp. 242-250, 2016.

[31] NEQS, "Pakistan environmental legislation and the National Environmental Quality Standards (NEQS), Government of Pakistan," 1997.

[32] K. G. Malle, "Zink in der Umwelt," Acta Hydrochimica et Hydrobiologica, vol. 20, no. 4, pp. 196-204, 1992.

[33] T. Khan, S. Muhammad, B. Khan, and H. Khan, "Investigating the levels of selected heavy metals in surface water of Shah Alam River (A tributary of River Kabul, Khyber Pakhtunkhwa)," Journal of Himalayan Earth Sciences, vol. 44, pp. 71-79, 2011.

[34] A. B. Tabinda, S. Bashir, A. Yasar, and M. Hussain, "Metals concentrations in the riverine water, sediments and fishes from river Ravi at Ballokiheadworks," Journal of Animal and Plant Science, vol. 23, pp. 76-84, 2013.

[35] A. B. Tabinda, S. Bashir, A. Yasar, and S. Munir, "Heavy metals concentrations in water, sediment and fish in river Sutlej at Sulemanki headworks," Pakistan Journal Of Zoology, vol. 45, no. 6, pp. 1663-1668, 2013.

[36] F. A. Oguzie and G. A. Okhagbuzo, "Concentrations of heavy metals in effluent discharges downstream of Ikpoba river in Benin City, Nigeria," African Journal of Biotechnology, vol. 9, no. 3, pp. 319-325, 2010.

[37] H. K. Akin and E. Unlu, "Heavy metal concentrations in water, sediment, fish and some benthic organisms from Tigris River,
Turkey," Environmental Modeling \& Assessment, vol. 131, no. 1-3, pp. 323-337, 2007.

[38] E. Królak and B. Zdanowski, "The bioaccumulation of heavy metals by the mussels Anodonta woodiana (Lea,1834) and Dreissena polymorpha (Pall.) in the heated Konin lakes," Archives of Polish Fishery, vol. 9, pp. 229-237, 2001.

[39] H. Liu, J. Yang, and J. Gan, "Trace element accumulation in bivalve mussels Anodonta woodiana from Taihu Lake, China," Archives of Environmental Contamination and Toxicology, vol. 59, no. 4, pp. 593-601, 2010.

[40] C. Gundacker, "Comparison of heavy metal bioaccumulation in freshwater molluscs of urban river habitats in Vienna," Environmental Pollution, vol. 110, no. 1, pp. 61-71, 2000.

[41] T. J. Newton and W. G. Cope, "Biomarker responses of unionid mussels to environmental contaminants," in Freshwater Bivalve Ecotoxicology, J. L. Farris and J. H. Van Hassel, Eds., pp. 257-284, CRC Press, Boca Raton, Fla, USA, 2007.

[42] A. K. Fritts, J. T. Peterson, P. D. Hazelton, and R. B. Bringolf, "Evaluation of methods for assessing physiological biomarkers of stress in freshwater mussels," Canadian Journal of Fisheries and Aquatic Sciences, vol. 72, no. 10, pp. 1450-1459, 2015.

[43] C. G. Goodchild, M. Frederich, and S. I. Zeeman, "AMPactivated protein kinase is a biomarker of energetic status in freshwater mussels exposed to municipal effluents," Science of the Total Environment, vol. 512-513, pp. 201-209, 2015.

[44] N. Pourang, C. A. Richardson, and M. S. Mortazavi, "Heavy metal concentrations in the soft tissues of swan mussel (Anodonta cygnea) and surficial sediments from Anzali wetland, Iran," Environmental Modeling \& Assessment, vol. 163, no. 1-4, pp. 195-213, 2010.

[45] O. Ravera, P. R. Trincherini, G. M. Beone, and B. Maiolini, "The trend from 1934 to 2001 of metal concentrations in bivalve shells (Unio pictorum) from two small lakes: Lake Levico and Lake Caldonazzo (Trento Province, Northern Italy)," Journal of Limnology, vol. 64, no. 2, pp. 113-118, 2005.

[46] O. Ravera, R. Cenci, G. M. Beone, M. Dantas, and P. Lodigiani, "Trace element concentrations in freshwater mussels and macrophytes as related to those in their environment," Journal of Limnology, vol. 62, no. 1, pp. 61-70, 2003.

[47] O. Ravera, G. M. Beone, R. Cenci, and P. Lodigiani, "Metal concentrations in Unio pictorum mancus (Mollusca, Lamellibranchia) from of 12 Northern Italian lakes in relation to their trophic level," Journal of Limnology, vol. 62, no. 2, pp. 121-138, 2003.

[48] E. D. Goldberg, "The Mussel Watch-a first step in global marine monitoring," Marine Pollution Bulletin, vol. 6, no. 7, p. 111,1975 .

[49] J. M. Neff, R. E. Hillman, R. S. Carr, R. L. Buhl, and J. I. Lahey, "Histopathologic and biochemical responses in Arctic marine bivalve molluscs exposed to experimentally spilled oil," Arctic, vol. 40, no. 5, p. 220, 1987.

[50] J. Wedderburn, I. McFadzen, R. C. Sanger et al., "The field application of cellular and physiological biomarkers, in the mussel Mytilus edulis, in conjunction with early life stage bioassays and adult histopathology," Marine Pollution Bulletin, vol. 40, no. 3, pp. 257-267, 2000.

[51] S. A. Khan, "Water quality characteristics of the Kabul river in Pakistan under high flow conditions," Journal of the Chemical Society of Pakistan, vol. 19, p. 20, 1997.

[52] G. Gold-Bouchot, R. Sima-Alvarez, O. Zapata-Perez, and J. Güemez-Ricalde, "Histopathological effects of petroleum 
hydrocarbons and heavy metals on the American oyster (Crassostrea virginica) from Tabasco, Mexico," Marine Pollution Bulletin, vol. 31, no. 4-12, pp. 439-445, 1995.

[53] N. J. Morley, "Interactive effects of infectious diseases and pollution in aquatic molluscs," Aquatic Toxicology, vol. 96, no. 1, pp. 27-36, 2010.

[54] A. Waseem, J. Arshad, F. Iqbal, A. Sajjad, Z. Mehmood, and G. Murtaza, "Pollution status of Pakistan: a retrospective review on heavy metal contamination of water, soil, and vegetables," BioMed Research International, vol. 2014, Article ID 813206, 29 pages, 2014. 

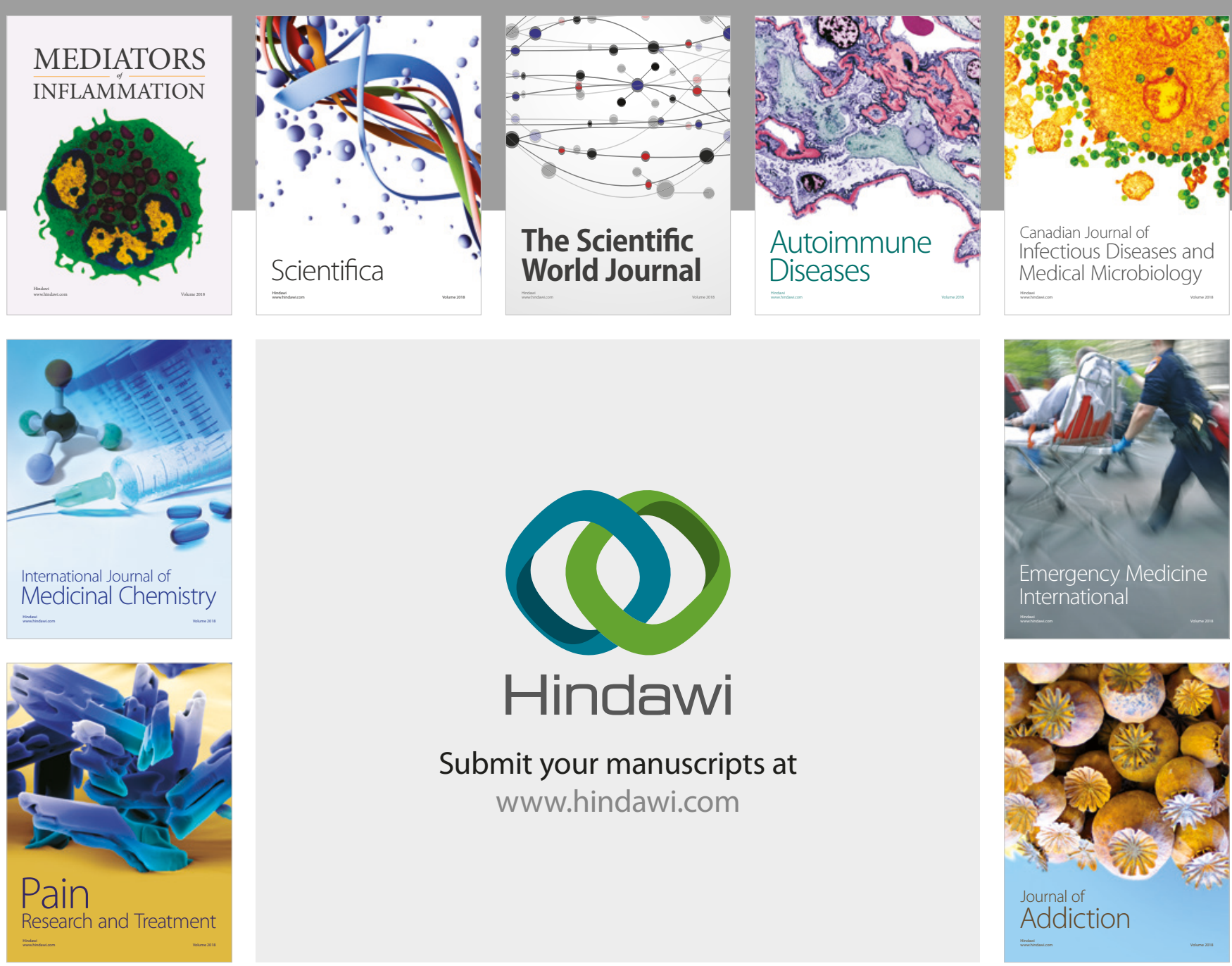

Canadian Journal of
Infectious Diseases and Medical Microbiology

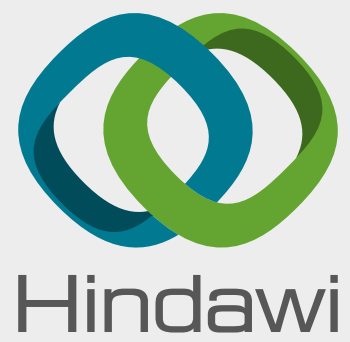

Submit your manuscripts at

www.hindawi.com
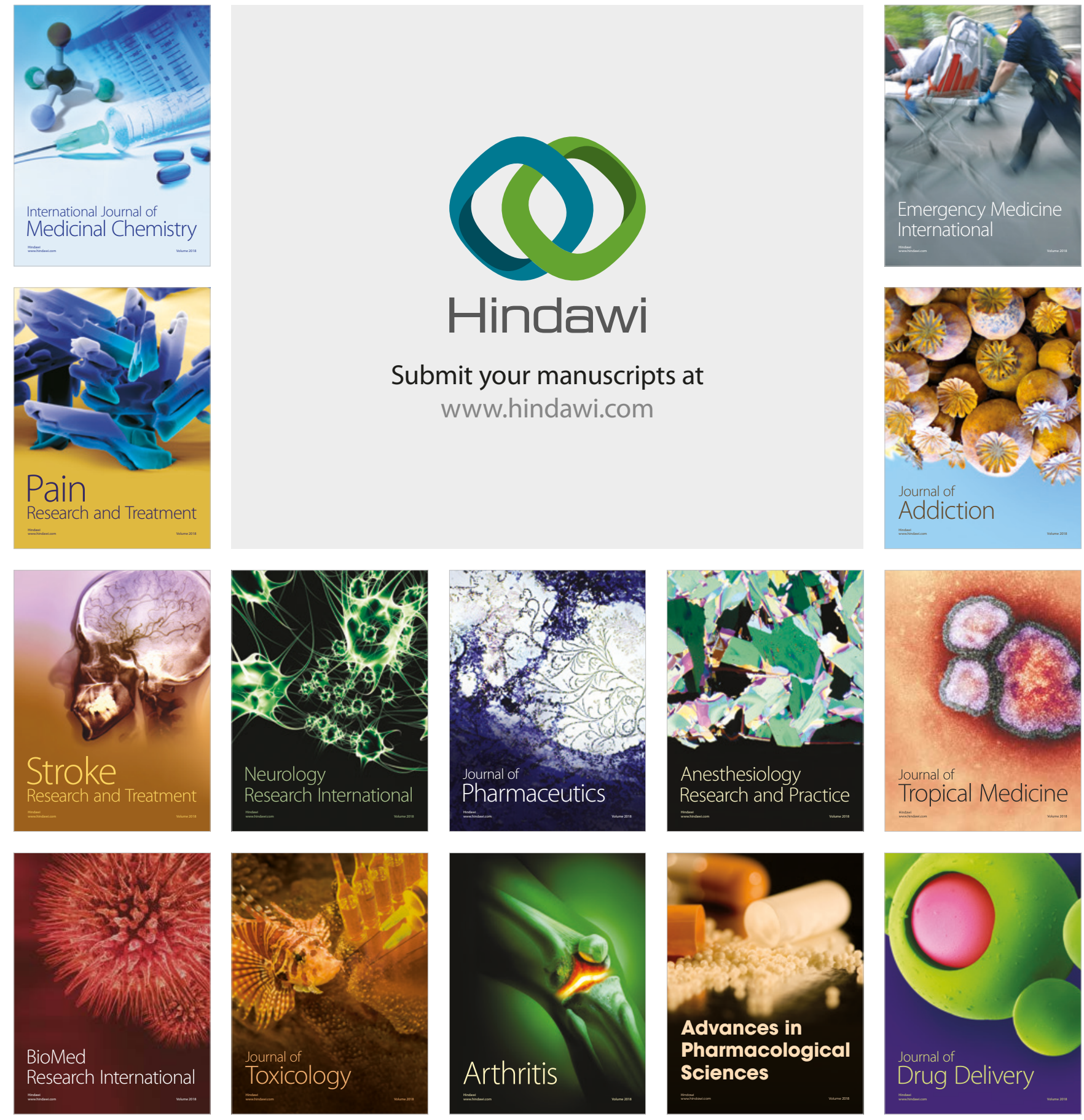